$\begin{array}{ll}\text { Balkanologie } & \text { Balkanologie } \\ \text { Revue d'études pluridisciplinaires }\end{array}$

Vol. $16 \mathrm{n}^{\circ} 1 \mid 2021$

Au-delà de la "route des Balkans ": mondes sociaux des circulations

\title{
"Back then, in the Corona...": Returning from the Convoluted Temporality of Bosnia and Herzegovina
} «En ce temps-là, pendant le Corona... »: sortir des contorsions temporelles de la Bosnie-Herzégovine

\section{Svjetlana Nedimović}

\section{(2) OpenEdition}

Journals

Electronic version

URL: https://journals.openedition.org/balkanologie/3124

DOI: 10.4000/balkanologie.3124

ISSN: 1965-0582

\section{Publisher}

Association française d'études sur les Balkans (Afebalk)

\section{Electronic reference}

Svjetlana Nedimović, "'Back then, in the Corona...": Returning from the Convoluted Temporality of Bosnia and Herzegovina", Balkanologie [Online], Vol. 16 n 1 | 2021, Online since 01 June 2021, connection on 03 October 2021. URL: http://journals.openedition.org/balkanologie/3124 ; DOI: https:// doi.org/10.4000/balkanologie.3124

This text was automatically generated on 3 October 2021.

(C) Tous droits réservés 


\section{"Back then, in the Corona...": Returning from the Convoluted Temporality of Bosnia and Herzegovina}

«En ce temps-là, pendant le Corona... » : sortir des contorsions temporelles de la Bosnie-Herzégovine

Svjetlana Nedimović

1 "Back then, in the Corona..." As numbers of the COVID-infected were rising across Bosnia and Herzegovina (BiH), over the summer and into the autumn of 2020, this phrase appeared as a common opening to individual stories and a new temporal reference that replaced "the war" as the major landmark in personal and collective lives. Corona had already become the past, equated with the days of the lockdown, even though more COVID-19 infections came after the lockdown ended. After lockdown, the death toll increased sharply and became more intimate - as it penetrated close circles. Yet the language of the collective everyday was stubbornly shaking off statistical reality and juggling the past and present. People were living a future as if it were the present, while pushing the threatening present into the past. The incomprehensible experience of a deadly disease was confined to those most intimate spaces of fear into which individuals plunged, only when exposed through contacts or falling ill themselves. The new experience and new reality were thus themselves locked into the manageable and controlled interval of the lockdown, and their spill-over into everyday reality constituted a troubling transgression. A country widely considered to be a hostage to its past had suddenly projected itself into the illusion of future.

2 This topsy-turvy temporality is probably not peculiar to BiH. Could there be there a deeper layer of meaning to it, beyond the obvious shunting away of a new, perilous reality? 


\section{The New Normality Is the Old Normality Cast in Sharp Relief}

3 There indeed is an element of denial of the present reality, but this is also rooted in certain and familiar patterns. To the people of $\mathrm{BiH}$, who are constantly bombarded with corruption scandals, any scenario involving a hoax - a trick of fate or some other force - is believable. They have lived their lives for the last three decades from one deadly hoax to another. Once Yugoslavs, they were cheated out of their stable reality and thrown into uncertainty. Everything they knew of themselves and their world was perverted and devastated: their country was shattered in bloodshed, and its successor state(s) -torn apart, looted and unable to mend. To survive, anything that escapes direct individual control, such as the pandemic, must be pushed away.

The order of things has long been stable in its disorderly condition. So there is a good share of logic to the confused temporality of the days of COVID-19. While the media, internationally but also in $\mathrm{BiH}$, talk of "new normality," this normality feels awfully like the old one.

5 Wearing a mask and ensuring physical distance leave the deeper strata of reality untouched: the underpaid are still underpaid, only more so. The unemployed are more numerous. The workers unprotected at work are still exposed to various hazards, now with the notable addition of COVID-19. The health sector is trapped in the vicious circle of budget cuts and rising requirements, which in turn are caused by budget cuts to the programs of long-term prevention and ongoing care.

The cracks in the economy, which the transition pushed away from industrial production into the service sector and underpaid jobs, are deepening. The country is being plunged into the abyss of debt in order to barely subsist. Now that it is denied IMG loans, problematic as they are, it is resorting to selling state bonds and commercial bank loans. In the background of the tragedy of the pandemic, which catapulted $\mathrm{BiH}$ to the top of the world list in terms of the Covid-related mortality rate, dozens of longterm tragedies are unraveling. ${ }^{1}$

7 The waves of Coronavirus infections, with each wave being evidently worse than the previous, have generated tidal waves of public anger. They have sprung from different kinds of frustrations - some with the restrictions and the high-level corruption scandal of the purchase of inadequate respirators, but some with the general inability of state institutions to provide assistance in all fields of social life. The tragic lack of vaccines and delayed attempts to buy any more substantial quantities is but the most prominent example. The shortage has disclosed pervading social injustice since the allocation of vaccines privileges - once again - the haves over the have-nots.

The second year into the pandemic, a year prior to the general elections, we see a full revival of pre-Corona BiH politics - the well-rehearsed Menuetto of sovereignty issues, national interest, comparative counting of war victims. As usual, party politics is staying well clear of the deepening crisis of everyday living and communal problems, from dilapidated water-supply infrastructure and the health hazards of waste disposal, to the increasing burden of global migrations.

9 The society, in the background, is burying the dead more or less quietly, and bidding farewell to the incessant flow of its youth westward. 

which has affected a bit more significantly only the middle class, or upper-middle class, insofar as it has removed the glitter of Instagrammed travels and shopping excursions from reality.

11 The phrase "back then, in the Corona" is therefore layered with irony. It projects a future, but also does not suggest a passage to the future. It does not even finish construing a collective delusion before it resists the temptation to believe that Corona could bring about a transformation of the world. It reflects the condition of a society in which no historical temporality has made sense over the last three decades.

The old pre-pandemic normality most violently and visibly exploded social reality here in BiH and other Yugoslav republics in the 1990s. ${ }^{2}$ That, once-new "transition" reality has considerably shaped our present-day experience of pandemic - from the lack of collective organization, to the unwillingness of people to accept the authority of public interest as the ground for restrictions upon individual lives. Our response to the pandemic comes as no surprise, given the local and international campaigning against public interest and marketing of the hegemony of the private. From this moment in time, the break-up of Yugoslavia seems less a historical aberration, and more an ominous prophecy of the future of societies at the hands of private interests.

\section{Unleashing the Potentials behind the "Locked-Down" Temporality}

13 If everything has been changed so that nothing of substance would change, is it not pragmatic simply to remain in one's tracks? To shuffle the past, present and future in a way that voids them of meaning, so that we are liberated from expectations and illusions of movement forward?

14 In 2020, the first year of the pandemic, it certainly seemed so.

15 In 2021, there is commotion and simmering under the surface that breaks through the above interpretative framework. The societal undercurrents are whirling and the dull surface of reality is showing creases.

Despite the restrictions, mass protests may well be more frequent than before. There were several on 1 May, Labor Day, in Sarajevo: coalminers forced to pay the price of bureaucratic mismanagement during the long transition and of the more recent (and unjust) EU-enforced "green transition"; metal workers of a dying industry; the service sector union; and a Women's March Movement. They all demonstrated against the incompetent government and demanded mass vaccination.

17 For the time being, it is premature to talk of the rise of a broad transformative social movement. As many times before, commentators are easily tempted to project high expectations and offer unsolicited advice to those marching in the streets. The odds against the protest movements, however, are the same as those faced by their predecessors back in 2008 (over the murder of a minor on a Sarajevo tram), 2013 (for a resolution to the crisis of citizen ID numbers) and 2014 (February protests amounting to a social uprising and a nation-wide attempt to restore direct democracy in the form of popular plenum). The wave rises high but gets halted easily; collective organization remains laborious and misunderstood. Hence party politics quickly takes over with the usual array of coalitions, assembled and reassembled, entertaining inter-party

Balkanologie, Vol. $16 n^{\circ} 1$ | 2021 
transfers and bickering over sovereignty within the state that has failed to manifest any of its attributes.

But the truly new comes surprisingly from the struggles that have been around for a longer time - the decades of political activism are bearing fruit. Contrary to the expectations that the global crisis of pandemic would dominate fields of contestation, we see broadening and intensification of struggles that once seemed local and marginal.

\section{The Present Reclaimed}

The struggle that has marked the last decade in $\mathrm{BiH}$ is the struggle of local communities to preserve their rivers from small hydropower plants that devastate riverbeds and canyons, while literally killing rivers and life in them, as the last drop of water is channeled into pipes for the profit of a handful of private investors.

Over the years, the movement has grown silently in the shadow of political games around sovereignty and identity with which the financial and political elites have saturated BiH's political atmosphere. Grassroots groups have persisted in their struggle for rivers, which nowadays seems like a struggle for the people themselves -their survival and living, but also the autonomy, their freedom to decide on their living.

People from different parts of the country, "Guardians of the Rivers" (River Guardians) have joined forces. Inter-entity and ethnic lines are crossed liberally and ignored when it comes to solidarity in struggle. While preferences in terms of institutional party politics may not have been altered significantly for River Guardians, their deeper political sense has developed through (joint) resistance and work. At the time of Corona, they are disentangling the knot of convoluted temporality, the capture of the present by the past, and of the future by the present, with a clear projection of their struggle forward.

The struggles have intensified, and the front is stronger, more unified and resolute. Regional ties have been fostered. ${ }^{3}$

Throughout this time, groups have operated with zeal and strategic rationality, through direct actions of blocking construction (the Željeznica, the Kruščica, the Neretvica, the Bjelava and others), protest gatherings, ferocious and witty campaigns in social and mass media, but also legal actions, legislative initiatives, pressures and lobbying. They have never allowed themselves to be constrained by tactical puritanism - the ideational basis is beyond compromise but pragmatism is embraced in action.

It can now be said with certainty that they have won the battle for hearts and minds. Small hydropower plants are seen as a great evil and irreparable damage to the society and its future. ${ }^{4}$ The battle for the rivers, however, continues. As situations arise, local groups come to each other's aid. ${ }^{5}$

The main principles and assumptions upon which the groups operate are summarized in the "Manifest for Water," one of the rare truly transformative documents to emerge from society over the last several decades. The Manifest that came out in October 2020 strategically ties three temporal dimensions into a politically meaningful project. It builds on the experience of the grassroots struggles, immediate and real. It stands firmly in the present, which is unmasked and confronted without fear and in full understanding of entangled global and local problems, with lines like the following: ${ }^{6}$ 
Water across the world is running scarce.

Rivers and springs of fresh water are endangered by the climate crisis. The crisis is produced by the policies of uncontrolled economic growth and rampant exploitation of nature for profit.

Global problems are translated into the local context and confronted without any attempt at shunning away from responsibility. ${ }^{7}$ The global and the local, the general and the particular, merge into a succinct and symbolic diagnosis of our times:

Our waters are threatened by private interests.

The Manifest points to the future in a programmatic statement, which combines pressure upon institutions with a straightforward promise. It calls for the constitutional protection of water at all levels. ${ }^{8}$ This is complemented with a list of more specific legislative motions and executive policies which uses the institutional architecture and legal framework without, however, constraining the transformative effort within the limitations of the given circumstances.

At the same time, the Manifest makes a promise - "Here we stand" - and states the responsibility for the defense of water. The document calls for societal control over this vital resource while at the same time effectively establishing such control:

We are taking the historic responsibility and duty to preserve our water. As we have done in the past, we shall courageously guard and selflessly defend our rivers....

At the same, the groups are situating themselves within the current planetary crisis and the global movement for climate justice. ${ }^{9}$

The document and the bearers of promise thus escape the knot of temporality which long-term historical despair and immediate crisis have produced. The convoluted temporality expressed in popular discourse, "back then, in the Corona," treats the unbearable present as the past, in order to move to an unrealistic form of future which is repeating the patterns of exploitation and domination, but being familiar, it shields people from new perils that the pandemic entails.

1 In contrast, the River Guardians stand firmly in the present, and this is what the solid ground of their past struggles has done for them. It allows them to project their action into the future. The struggle which is specific can be mapped onto a broader revolutionary horizon now opening up by the new circumstances: the pandemic has made it evident that our relating to society and nature must change radically. The now, therefore, does not block the River Guardians since their struggle, for environment but also collective autonomy, speaks to the now.

2 To get to that point, paradoxically but revolutionarily, they proclaim that they are already there - this is how the Manifest ends:

Profiting privately from our water and our existence is over.

We are taking the historic responsibility and duty to preserve our water. As we have done so far, we shall defend our rivers courageously and regardless of sacrifice needed, and protect all our waters against anyone who attempts to encroach upon them.

In their capacity as the doers of deeds, hardened by praxis, the River Guardians thus make a solemn promise. As Hannah Arendt in On Revolution reminds us, "the making and keeping of promises [...] in the realm of politics, may well be the highest human faculty," as promises have a world-building capacity: they "deal with the future and provide stability in the ocean of future uncertainty." ${ }_{10}$ The struggle, and the Manifest 
arising from it, restore history (which is made of human doing) within a chaotic temporality. The struggle does not control the future but participates in it.

\section{NOTES}

1. Among them two are paradigmatic: the plight of coal mines and miners, once national heroes of development after the Second World War and now a burden to be dumped for the dream of green transition, and the drama of people on the move trapped in the camps along the state border.

2. When the edifice of socialist Yugoslavia came down, the destruction was accelerated and total. It was not about a state being disintegrated and political transformation. It was a worldshattering event. Yugoslavia had been the present, but the making of Yugoslavia had also formed the entire temporal framework of human lives. In this way, the country was firmly anchored in the past and projected into the future as utopian - however-more-distant it became with the fading of the revolution. Yugoslavia's history, in the sense of a historical movement and not just a narrative of the past, structured both collective and individual subjectivities. This is why there really is no love lost in this part of the world for the now-old normal that followed Yugoslavia's disintegration.

3. In April 2021, BiH representatives joined the great Eco Uprising in Belgrade (Serbia) that gathered numerous environmental activists from different parts of the Western Balkans.

4. Most uniquely, the River Guardians also succeeded in pressuring the European Energy Community to make a clear statement against the plants as a source of green energy - which was previously cautiously avoided as companies from the EU, some even partly state-owned such as Austrian Kelag, had also joined the "scramble" for Balkan rivers.

5. Most groups have formed local civic associations in order to be able to file lawsuits. Their cooperation network has not suffered from the excess of formality. In the matters of entity and state relevance they appear as the fairly loose $\mathrm{BiH}$ Coalition for River Protection in which they are joined by some of the bigger non-governmental organizations that work on a range of environmental issues across the country. While there are inevitable points of disagreement, those have never hindered the coalition's ability to act upon its principles and for its main goal in contrast to many other such networks that sprang up from social movements in BiH.

6. The quotes to follow are from "Manifest for Water - River Guardians for the Preservation and Defense of the Water of Bosnia and Herzegovina," October 2020. Translations by the author S.N. 
Online:

https://voda.ekoakcija.org/sites/default/files/dokumenti/

manifest_o_ocuvanju_vode_u_bosni_i_hercegovini.pdf (accessed in June 2021).

7. "The waters of the Balkans are in danger. They are rapidly falling prey to local tycoons, foreign profiteers and their protectors within the government. If we do not defend our wild rivers and abundant springs of fresh water, if we do not provide them with lasting protection, we shall be the last generations to remember them," ibid.

8. This in itself is revolutionary for $\mathrm{BiH}$ insofar as the calls for constitutional changes have so far concerned mechanisms of inter-ethnic balancing and power-sharing.

9. "In the circumstances of social inequalities and injustice, climate crisis and increasing risks of fatal pandemics, absolute priority of society and state must be the survival and balanced development of human communities and wild life. We, the guardians of BiH rivers, together with progressive forces across the world, embrace the duty to care for our planet and the principle of climate justice as the only proper response to the climate crisis," ibid.

10. ARENDT Hannah, On Revolution, London and New York, Penguin Books, 1990, p. 175.

11. The quote is from the working draft of the founding act which is not yet available for publication. Translation by the author S.N. who participated in drafting this document as well as the Manifest.

\section{AUTHOR}

\section{SVJETLANA NEDIMOVIĆ}

Riječ i djelo (www.rijecidjelo.ba), Sarajevo

svjetlana.nedimovic[at]gmail.com 